\begin{tabular}{|c|c|c|}
\hline Beitr. Ent. & Keltern & ISSN 0005-805X \\
\hline $\mathbf{5 6}(2006) 1$ & S. $189-198$ & 15.08 .2006 \\
\hline
\end{tabular}

\title{
A preliminary study of Cylindridia CASEY, with descriptions of new species from Middle America
}

\section{(Coleoptera: Curculionidae: Baridinae)}

With 28 figures

Jens Prena

\section{Summary}

The known range of Cylindridia CASEY is extended from North into Middle and South America. Cylindridia nitidissima (CASEY), C. perexilis CASEY and C. simulator CASEY are new synonyms of C. prolixa (LECONTE). Three new species are described from high elevations in Middle America: $C$. propinqua sp. $\mathbf{n}$. from southern Mexico, and C. fuscipes sp. n. and C. mibripes sp. n. from Costa Rica. A fifth, still unidentified species is recorded from Santa Catarina, Brazil.

\section{Zusammenfassung}

Das bekannte Verbreitungsareal von Cylindridia CASEY wird von Nord- auf Mittel- und Südamerika ausgedehnt. Cylindridia nitidissima (CASEY), C. perexilis CASEY und C. simulator CASEY sind neue Synonyme von C. prolixa (LeConte). Drei neue Arten werden aus hohen Lagen in Mittelamerika beschrieben: C. propinqua sp.n. aus Südmexiko, und C. fuscipes sp. n. und C. rubripes sp. n. aus Costa Rica. Eine fünfte, bislang nicht identifizierte Art wird aus Santa Catarina, Brasilien gemeldet.

Key words

Weevils, new species, Cylindridia, Cyperaceae, Neotropics

Introduction

CASEY (1892) recognized five informal subgroups (subgenera I-V) when he adopted and extended the definition of Limnobaris BEDEL for the inclusion of certain North American Baridinae. This provisional classification formed the basis for his later description of Cylindridia and five other genera (CASEY 1920). Four species were included in Cylindridia at this occasion, and no further reference has been made to this genus ever since, except for catalogues and faunal lists. New material now extends the known distribution to the Neotropical region. The primary objective of this study is to contribute to the Costa Rican inventory of biodiversity. The study remains preliminary because of its regional restriction to North and Middle America, and the still insufficient knowledge of several 
related genera. In particular the North American genus Dirabius CASEY requires revision before Cylindridia can be re-defined and distinguished from the numerous other groups associated with Cyperaceae and Poaceae (including Bromeliaceae).

The study was carried out as part of the ALAS 4 project (NSF grant DEB-0072702, National Geographic Society grants 7331-02, 7751-04), which contributes to the Costa Rican National Inventory of Biodiversity. The Deutsche Forschungsgemeinschaft provided complementary travel grants in 2004 and 05, when this investigation was conducted. Collections work at CMNC and CNCI was supported by the Canadian Museum of Nature's Nature Discovery Fund and Program, the Canacoll Foundation and the genuine hospitality of Bob \& Cathrin Anderson and Henry \& Anne Howden. Jack Longino and Alvaro Herrera managed efficiently all project-related issues. Carlos Víquez organized the expedition to Valle del Silencio, where most biological observations were made. José Gonzalez identified Rhynchospora miziana. Sincere thanks are extended to PhIL Perkins and the curators/collectors listed in the method section for providing or searching specimens. Pat Bouchard tracked historical records from Québec and made valuable suggestions which helped to improve the clarity and consistency of the text.

\section{Material and methods}

The study is based on approximately 370 specimens. The following codens are used to refer to institutional and private collections in the text.

CMNC Canadian Museum of Nature, Ottawa [incl. Howden material] (Bob Anderson, Françors GÉNIER)

CNCI Canadian National Collection of Insects, Ottawa (PAT Bouchard)

CWOB Charles W. O'Brien personal collection, Green Valley AZ

INBC Instituto Nacional de Biodiversidad, Sto. Domingo de Heredia (Angel Solís)

JPPC JeNs PRENA personal collection

MNHN Museum National d'Histoire Naturelle, Paris (HéLìne Perrin)

NMNH National Museum of Natural History, Washington DC (STEve Lingafelter, Lisa Roberts)

NSMC Nova Scotia Museum of Natural History, Halifax (Christopher MAJKA)

QMOR University of Montreal (Lourse ClOUTIER)

Specimens were reared in February/March 2005 by placing the culms of infested host plants in plastic bags and retrieving the emerged weevils over a period of approximately one month. Larvae and pupae were obtained from random subsamples of dissected plants and assigned to species (all C. rubripes) by using the adults that emerged from the same lot. The immature stages are not described here, but are available for comparative studies.

The size range of specimens is given as total length (without rostrum) and standard length (anterior margin of pronotum to elytral apex). All measurements were taken with an ocular micrometer in a dissecting microscope. Line-breaks of label-data are indicated as "/ ".

\section{Cylindridia CASEY}

Limnobaris auct., not BEDEL 1885-183. CASEY 1892.

Cylindridia CASEY 1920-493. Type species Centrinus prolixus LeConTe (by original designation).

Recognition: Species of Cylindridia can be recognized by the following character states and biological data: (1) body shape elongate, slender and parallel-sided, Fig. 1-3; (2) pygidium covered by elytral apices; (3) rostrum sexually dimorphic in terms of length and 
width, Fig. 21-28; (4) male with deep pectoral cavity and pair of slender, anteriorly projecting prosternal spines usually visible from above, both structures reduced or entirely absent in depauperate specimens; (5) fore tibia in both sexes with ventrodistal spur not larger than tarsal claw; (6) claws curved and separate at base; (7) larval development in pith of flowering culms of Cyperaceae.
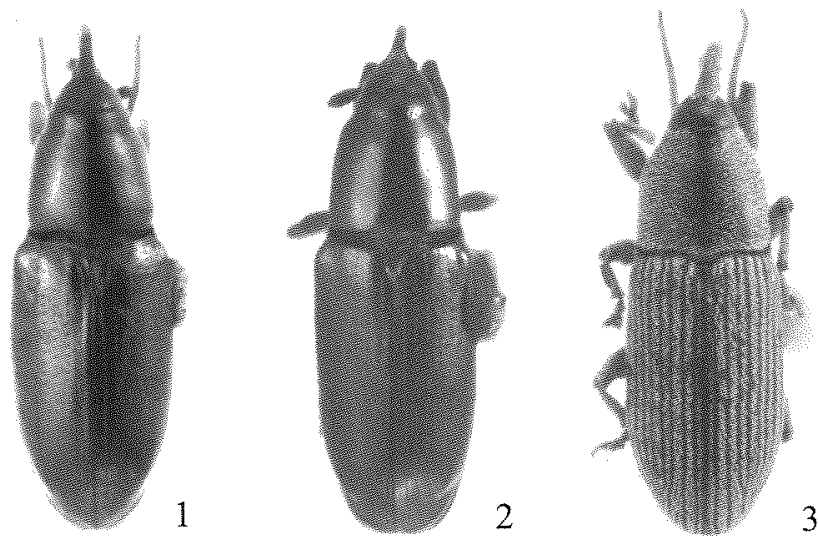

Fig: 1-3: Dorsal habitus of 1, C. rubripes, male; 2, C. fuscipes, female; 3, Cylindridia sp. A, male.

Discussion: Cylindridia is a genus with peculiar, anteriorly projecting prosternal spines that seemed to be restricted to the Nearctic region, whereas this character state occurs rather frequently in Neotropical genera. The southward extension of the range now adds to a geographically more consistent distribution of these weevils.

Species of Cyperaceae are the host of Cylindridia and numerous other genera in temperate (Böving 1924, Satterthwatt 1942, Palm 1957, Dieckmann 1991, Yoshihara \& Morimoto 1994) and tropical regions (Parnell 1970, Anderson \& Peck 1994, Yoshimara \& Morimoto 1997). Relatively few of them have the above mentioned spines. The most likely candidate to be confused with Cylindridia is Sibariops CASEY, species of which are less elongate and almost always (indistinct in a Costa Rican population of the $S$. confusus complex) possess a greatly enlarged, anteriorly directed spur at the apex of the fore tibia of the male. A future taxonomic revision of this genus shall explore its distinctiveness to Cylindridia based on representative material of the diverse South American fauna. The separation of the various genera becomes less clear, when the prosternal spines are disregarded in their classification. As this character state is extremely variable and its phylogenetic value remains unexplored, a concise diagnosis of Cylindridia is not possible at this stage and should be targeted in a comprehensive study of all relevant taxa, which are assigned to no less than three tribes at present.

Distribution: Neotropical (Mexico, Costa Rica, Brazil; new records) and Nearctic regions (U.S.A. and southern Canada, east of Rocky Mountains)

Life History [based on C. mbripes and C. fuscipes]: The female visits newly emerged culms of large-sized species of Carex, Rhynchospora and possibly other Cyperaceae, where it deposits single eggs in the lowest accessible, unsheathed portion of the apical internode. One to several males may congregate nearby, often in the inner angle of the adjacent leaf or in the developing inflorescence. Any usage of their prosternal spines, such as for ritual fighting over females as reported for Parisoschoenus expositus by EBERHard \& GarCia-C. 
(2000), has not been observed. The next oviposition on the same culm occurs, when new non-infested substrate of the old internode or a new unsheathed internode has grown basally. It appears, that the female probes whether or not sufficient non-infested tissue is available. Large culms may contain up to five specimens of different developmental stages, with the oldest specimen found in the apical section, the next-younger specimen boring in the basally adjacent 10-15 cm long section, and so on. The larva tunnels down part of the pithy interior of the culm, where it pupates among yellowish frass without preparing a cocoon. The host plant shows no evidence of physical damage or grossly impaired production of seeds, probably because the vascular system remains largely unaffected. The adult exits the now desiccated culm through a self-made spherical hole. Parasitic wasps were not encountered while rearing immatures from approximately 25 culms of Carex donnell-smithii and Rhynchospora ruiziana collected at two locations. Other weevils observed on the same hosts were Cholus foveolatus CHAmpIon, Molytini (up to three larvae in the short, succulent stem from where basal leaves and culm emerge; INBC) and an unidentified species of Macroscytalus Broun, Cossonini (larvae possibly in the seeds as suggested by exit-holes; JPPC).

\section{Key to the species of Cylindridia occurring in North and Middle America}

1 Derm aeneous, rarely with slight bluish or greenish metallic luster, flanks of pronotum and abdomen with white hairs; low and mid-elevations in United States and southern Canada (Nova Scotia, Québec, Ontario, Manitoba) east of Rocky Mountains.

C. prolixa (LECONTE)

Derm dark green to cupreous, with strong metallic luster, body glabrous, without discernable hairs; Middle America, high elevations between 2000-3100 m. 2

2 Antennal club compact, approximately as long as distal four funicular segments combined (Fig. 21); femora dark metallic, tibiae and tarsi red; southern Mexico.

C. propinqua sp. n.

Antennal club more elongate, at least as long as distal five funicular segments combined (Fig. 23); legs of uniform color, either dark metallic or reddish; Costa Rica (and probably western Panama). . .3

3 Legs red; elytral stria 10 not impressed subdistally; rostrum as long as or longer than pronotum; male without angularly projecting lamellar process ventrad of antennal insertion; female with rostrum weakly curved throughout (Fig. 23). C. rubripes sp. $\mathbf{n}$.

Legs dark metallic; elytral stria 10 impressed subdistally; rostrum shorter than pronotum; male with angularly projecting lamellar process ventrad of antennal insertion; female with rostrum notably curved in distal one-third (Fig. 25). C. fuscipes sp. $\mathbf{n}$.

\section{Cylindridia prolixa (LECONTE)}

Centrinus prolixus LeConte 1876-317. CASEy 1892-643 (placed in Limnobaris); CaSEy 1920-493 (placed in Cylindridia)

Limnobaris nitidissima CASEY 1892-644. CASEY 1920-493 (placed in Cylindridia); new synonymy

Cylindridia perexilis CASEY 1920-493. CASEY 1892-644 (specimen mentioned under L. prolixa); new synonymy

Cylindridia simulator CASEY 1920-493. CASEY 1892-644 (specimens mentioned under L. prolixa); new synonymy 
Redescription: Fig. 4-8. Total length 2.3-4.1 mm, standard length 2.2-3.8 mm, derm dark aeneous (occasionally bluish or greenish iridescent), with light-colored hairs particularly on flank, antenna and tarsi often (legs and rostrum occasionally) more-or-less brown, male with prosternal spines red; rostrum as long as (male) or longer (female) than pronotum, evenly curved in both sexes, lamellar process ventrad of antennal insertion not angularly projecting; antennal club moderate, approximately as long as distal five funicular segments combined; pronotum almost as long as wide, sides subparallel, constricted apically and tubulate in front; sides of aedeagus convex, apex blunt, body of aedeagus and apodemes of equal length, internal sac finely asperate, $1.5 \mathrm{x}$ longer than apodemes, minute basal sclerite present as lateral reinforcement of duct, tegmen with parameres slightly shorter than basal apodem; male sternite 9 with distal appendices moderately unequal.

Distribution: United States and adjacent southern Canada (Nova Scotia, Québec, Ontario, Manitoba) east of Rocky Mountain range [based on CHAGNON (1917), O'Brien \& Wibmer (1982), MajkA et al. (ms) and material of CMNC, CNCI, CWOB, JPPC, NMNH, NSMC, QMOR]

Plant association: Cyperaceae: Carex sp. (Observations: Askevold in Manitoba, PRENA in Vermont); occasionally visiting flowers of dicotyledonous plants, such as Eupatorium perfoliatum and Taenidia integerrima (HiLty 2005)

Discussion: My study of more than 100 specimens (CMNC, CNCI, CWOB, JPPC, $\mathrm{NMNH}$ ) from numerous collecting sites showed, that dry-mounted material looses its metallic sheen over time and exhibits generally a dull brownish tinge instead. This circumstance may explain partially the 1892 establishment of C. nitidissima ( 1 female) from Galveston, Texas. More recently collected material from Texas (CMNC, coll. R. Anderson) corroborates the synonymy with C. prolixa. Cylindridia similis (1 male, 3 females) and C.parexilis ( 1 female) were described from a single series collected by WICKHAM at Greeley, Colorado (CASEY 1920, p. 644), and lie within the variability of the material from elsewhere. The length of the male prosternal spines is variable and probably affected by the conditions imposed by the host plant and the environmental settings.

\section{Cylindridia propinqua sp. $\mathrm{n}$.}

Holotype male, Mexico, labeled: "7000', 32mi. S./ Valle Nacional,/ Oax. Mex. V.21-24,/1971 H. Howden” (CMNC).

Paratypes 3 ( 1 male, 2 females), Mexico, same label as holotype (CMNC 1, JPPC 2).

Description: Fig. 9-11, 21, 22. Total length 4.5-5.5 mm, standard length 4.2-5.2 mm; derm dark green with metallic luster, glabrous, tibiae and tarsi red; rostrum as long as (male) or longer (female) than pronotum, evenly curved in both sexes, lamellar process ventrad of antennal insertion not angularly projecting; antennal club compact, approximately as long as distal four funicular segments combined; pronotum almost as long as wide, sides slightly rounded, constricted apically and tubulate in front; sides of aedeagus convex, apex blunt, body of aedeagus shorter than apodemes, internal sac slightly longer than apodemes, with asperities coarse in basal one-third and finer distally, basal sclerite consisting of short flagellum with pair of slender hook-like appendages, tegmen with parameres shorter than basal apodem; male sternite 9 with distal appendices very unequal. 
Distribution: Mexico, Oaxaca, approximately $2150 \mathrm{~m}$ elevation

\section{Plant associations: Unknown}

Epithet: The name is a Latin adjective meaning "related".

Discussion: This is the only known record for a species of Cylindridia from Mexico. Without dissection, the most obvious difference to the otherwise very similar Costa Rican C. rubripes is the compact antennal club and the metallic color of the femora. However, several details of the male genitalia differ significantly from those of the Costa Rican species, while agreeing much better with those of the North American C. prolixa.

\section{Cylindridia rubripes sp. n.}

Holotype male (dissected), Costa Rica, labeled: "COSTA RICA: Prov. Heredia:/ 6km ENE Vara Blanca, $1950-/ 2050 \mathrm{~m}, 10^{\circ} 11^{\prime} \mathrm{N} 84^{\circ} 07^{\prime} \mathrm{W} / \mathrm{leg}$. J. Prena, 21.-25.4.2004/ INBio-OET-ALAS transect" (INBC).

Paratypes 202 (92 males, 110 females), Costa Rica, labeled: as holotype (JPPC 13); same data except 20.4.2002, 20/RG/RVC/011, INB0003230282 (INBC 1); same data except 15.III.2002, 20/RG/DBM/007 (INBC 1); same data except 14.IV.2002, 20/RG/DBM/011 (INBC 1); "COSTA RICA: Heredia/ Cerro Chompipe/ $10^{\circ} 05^{\prime} 20^{\prime \prime N}, 84^{\circ} 04^{\prime} 30^{\prime \prime W} / \mathrm{ca}$. $2 \mathrm{~km}$. N. Monte de la/ Cruz, 2000m, 12.VI.1997/ R. Anderson, cloud forest/ 97-012-X, on Cyperaceae." (CMNC 18); "COSTA RICA, Prov. Limón:/ P.N. La Amistad, Valle del/ Silencio, $10 \mathrm{~km} \mathrm{NE}$ Altamira,/ $2500 \mathrm{~m}, 9^{\circ} 07^{\prime} \mathrm{N} 82^{\circ} 58^{\prime} \mathrm{W}, / 24.2 .-26.2 .2005$, leg. J. Prena” (JPPC 13, MNHN 2); "COSTA RICA, Cart. Rd./ to Biol. Sta. Cuerisi [Cuericí],/ 2600m. VIII-28-1998/ C.W. \& L.B. O'Brien", "on/ Cyperaceae" (CWOB 10); "COSTA RICA, Cart./ Biol. Sta. Cuerisi [Cuericí],/2600m. VIII-28-1998/ C.W. \& L.B. O’Brien", "on/ Cyperus" (CWOB 11); "COSTA RICA: Prov. San José:/ R.F.

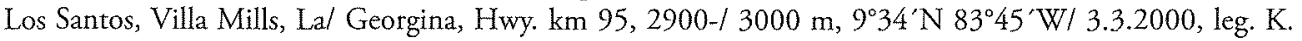
Nishida" (JPPC); same data except last line "3.-6.3.2005, leg. J. Prena" (JPPC 72, MNHN 2); "COSTA RICA, Cart. Cer-/ ro de la Muerte, Villa/ Mills, 3000m. VII-IX-1990,/ malaise trap, P. Hanson" (CWOB 1); "COSTA RICA, S.J.,/ 26mi.N. [on highway from] San Isidro/ del General, 10,500'/ VI-23-1974", "C.W. \& L.B. O'Brien/ \& G.B. Marshall” (CWOB 1); "COSTA RICA, S.J.,/ 29mi.N. [on highway from] San Isidro/ del General, 11000//VI-23-1974", "on Carex/ lehmanniana", "C.W. \& L.B. O'Brien/ \& G.B. Marshall" (CWOB 43); same data except "ex Carex / sp." (CWOB 2); "COSTA RICA, S.J./ 29mi.N. [on highway from] San Isidro/ del General, 11000'/ VII-10-1974", "C.W. \& L.B. O’Brien/ \& G.B. Marshall", "on Chusqueal subtesselata" (CWOB 5); same data without plant association (CWOB 2); "COSTA RICA, S.J./ 33mi.N. [on highway from] San Isidro/ del General, 10500'/ VII-10-1974", "C.W. \& L.B. O'Brien/ \& G.B. Marshall" (CWOB 2); "COSTA RICA, S.J.,/ 32mi.N. [on highway from] San Isidro/ del General, 10,500'/ VI-22-1974 C.W. \& L./ O'Brien \& Marshall” (CWOB 1).

Description: Fig. 1, 12-15, 23, 24. Total length 2.4-5.8 mm, standard length 2.3$5.6 \mathrm{~mm}$; derm dark green with metallic luster, glabrous, legs red, rostrum and antenna fuscous to partially red ( $>2500 \mathrm{~m}$ elevation); rostrum approximately as long as or longer than pronotum, curved basally in male, nearly straight in female, lamellar process ventrad of antennal insertion not angularly projecting; antennal club elongate, at least as long as distal five funicular segments combined; sides of aedeagus subparallel, apex pointed or round (small specimens at $3000 \mathrm{~m}$ elevation), body of aedeagus and apodemes of subequal length, internal sac as long as apodemes, with complex blade-like basal sclerite, tegmen with parameres slightly shorter than basal apodem; male sternite 9 with distal appendices very unequal.

Distribution: Costa Rica (with one site near Panamanian border), Cordilleras Central and Talamanca, 2000-3100 $\mathrm{m}$ elevation. 

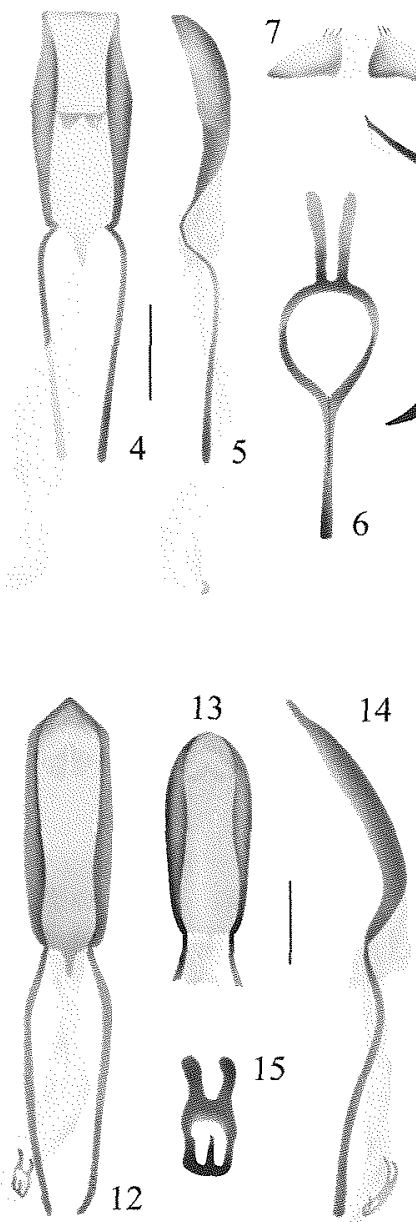

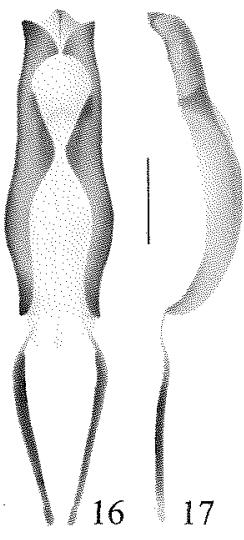

19
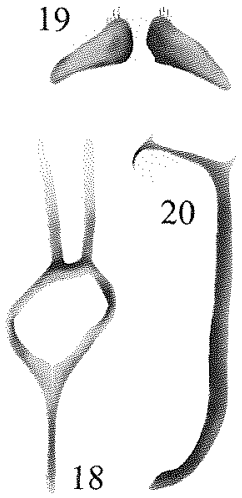

Fig: 4-20: Male genitalia and associated structures. 4-8, C. prolixa: 4-5, aedeagus, dorsal and lateral; 6, tegmen; 7-8, stemites 8 and 9.9-11, C. propinqua: 9-10, aedeagus, dorsal and lateral; 11, basal sclerite. 12-15, C. rubripes: 12-14, aedeagus, dorsal and lateral (13, high-elevation form from Villa Mills, $3000 \mathrm{~m}$ ); 15, basal sclerite. 16-20, C. fuscipes: 16-17, aedeagus, dorsal and lateral; 18, tegmen; 19-20, sternites 8 and 9. Scale bars $0.25 \mathrm{~mm}, 11$ and 15 scaled by factor 3 .

Plant associations: I reared 11 specimens from Carex donnell-smithii in Valle del Silencio, O'Brien collected two specimens ex Carex sp. in Villa Mills. Adult weevils were collected from Carex lemanniana (O'Brien \& Marshall 43), Carex sp. (Prena 2), Cyperus sp. (O'Brien 11), Rhynchospora ruiziana (Prena 88), unidentified Cyperaceae (Anderson 17, O'BRIEN 10) and Chusquea subtesselata (O'BRIEN 5). The latter association, with a species of Poaceae, might be accidental.

Epithet: The name is a compound Latin noun referring to red legs.

Discussion: I include under $C$. mbripes specimens with reddish legs and a characteristic blade-like basal sclerite in the male (Fig. 15). However, their morphological range is noteworthy. An analysis of the meristic data reveals statistically significant differences 
between local populations: (1) the length-width ratio of the pronotum decreases linearly with increasing altitude, (2) the standard length decreases exponentially with increasing altitude, and (3) the length of the ante-antennal portion of the rostrum differs from site to site without obvious altitudinal effect. A gradual transition is apparent in the length-width ratio of the body of the aedeagus over the entire altitudinal range, while the apical shape changes at approximately $2500 \mathrm{~m}$ from triangularly pointed (Fig. 12) to round (Fig. 13); the shape is intermediate in specimens from Cuerici. At $3000 \mathrm{~m}$, male specimens consistently exhibit greatly reduced prosternal spines. For distinction from the other Costa Rican species, C. fuscipes, see discussion there.

\section{Cylindridia fuscipes sp. n.}

Holotype male (dissected), Costa Rica, labeled: "COSTA RICA, Prov. San José, R. F./ Río Macho, Est. Ojo de Agua./ Alrededor de la Estación. 3000m. 27/ ABR 1997. B. Gamboa. Red de Golpe/ L_S_396500_ 482050 \#46760", CRI002 565388 (INBC).

Paratypes 26 (12 males, 14 females), Costa Rica, labeled: "COSTA RICA. Prov. San José, R.F./ Los Santos, Centro turístico Mirador de/ Quetzales, Send. Mirador de Quetzales,/ 2755m, 1 MAY 2002, R. González,/ Golpe, L_S 398799_479741 \#69451", INB0003484893 (INBC 1); "COSTA RICA: Prov. San José:/ R.F. Los Santos, Fca. E./ Serrano, Hwy. km 70, 2600-/ 2700m, 9³8'N 8351'W/ leg. J. Prena, 13.-16.5.2004" (JPPC 5); "COSTA RICA: Prov. San José:/ R.F. Los Santos, Villa Mills, La/ Georgina, Hwy. km 95, 2900-/ $3000 \mathrm{~m}, 9^{\circ} 34^{\prime} \mathrm{N} 83^{\circ} 45^{\prime} \mathrm{W} / 3 .-6.3 .2005$, leg. J. Prena" (JPPC 8); "COSTA RICA, S.J.,/26mi.N. [on highway from] San Isidro/ del General, 10,500'/ VI-23-1974", "C.W. \& L.B. O’Brien/ \& G.B. Marshall” (CWOB 1); "COSTA RICA, Prov. Limón:/ P.N. La Amistad, Valle del/ Silencio, 10km NE Altamira,/ $2500 \mathrm{~m}$, $9^{\circ} 07^{\prime} \mathrm{N} 82^{\circ} 58^{\prime}$ W,/ 24.2.-26.2.2005, leg. J. Prena" (JPPC 8); "COSTA RICA: Prov. Heredia:/ 6km ENE Vara Blanca, $1950-/ 2050 \mathrm{~m}, 10^{\circ} 11^{\prime} \mathrm{N} 84^{\circ} 07^{\prime} \mathrm{W} / \mathrm{leg}$. J. Prena, 21.-25.4.2004/ INBio-OET-ALAS transect" (JPPC 1); same label except line 4"9.4.2002", "20/M/04/064" (INBC 1); "COSTA RICA: Heredia/ Cerro Chompipe/ $10^{\circ} 05^{\prime} 20^{\prime \prime N}, 84^{\circ} 04^{\prime} 30^{\prime \prime W} / \mathrm{ca}$. 2km. N. Monte de la/ Cruz, 2000m, 12.VI.1997/ R. Anderson, cloud forest/ 97-012-X, on Cyperaceae" (CMNC 1).

Description: Fig. 2, 16-20, 25, 26. Total length 3.3-4.9 mm, standard length $3.2-4.7 \mathrm{~mm}$, derm dark green (occasionally bluish iridescent) with metallic luster, glabrous, rostrum and legs fuscous with metallic luster, antenna fuscous; both sexes with rostrum shorter than pronotum, curved in apical one-third (female) or throughout (male), male with angularly projecting lamellar process ventrad of antennal insertion; antennal club elongate, at least as long as distal five funicular segments combined; pronotum longer than wide, sides subparallel, constricted apically and tubulate in front; sides of aedeagus bisinuate, apex sinuate, dorsum with 2-layered proximal lobe on each side, apodemes shorter than body of aedeagus, internal sac short, basal sclerite absent, tegmen with parameres and basal apodem of subequal length, male sternite 9 with distal appendices very unequal.

Distribution: Costa Rica (with one site near Panamanian border), Cordilleras Central and Talamanca, 2000-3100 m elevation

Plant associations: I reared two specimens from Carex donnell-smithii and five specimens from Rhynchospora ruiziana in Villa Mills. Adult weevils were collected from Carex donnell-smithii (Prena 7), Rhynchospora ruiziana (Prena 1) and unidentified Cyperaceae (ANDERSON 1).

Epithet: The name is a compound Latin noun referring to dark legs.

Discussion: Cylindridia fuscipes occurs together with C. rubripes, and both species can be found even on the same individual plant. In almost all cases ( $I$ noticed one exception in 
230 specimens), they can be distinguished by the color of the legs as indicated by the epithets. The outer elytral stria of $C$. fuscipes generally is impressed near the apex, but not so in C. rubripes. Further useful character states for separating the two species are, for females, the curvature of the rostrum and, for males, the presence of an angular lamellar process below the antennal insertion.
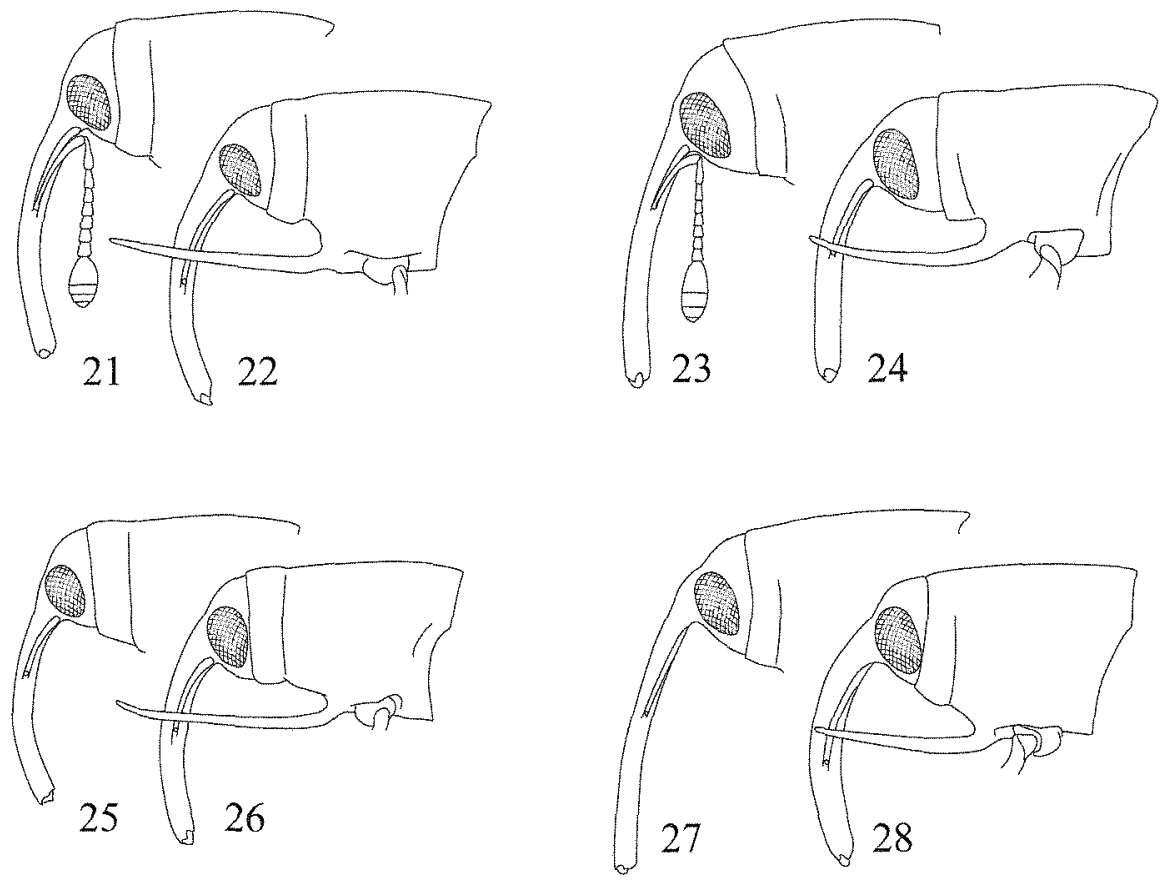

Fig: 21-28: Head and prothorax, lateral. C. propinqua: 21, female; 22, male. C. rubripes: 23, female; 24, male. C. fuscipes: 25, female; 26, male. Cylindridia sp. A: 27, female; 28, male.

\section{Cylindridia sp. A}

Description: Fig. 3, 27, 28. Total length 3.5-5.6 mm, standard length 3.2-5.3 mm, derm reddish brown to brown, head and rostrum darker, mat, with whitish club-shaped scales, rostrum little (males) or distinctly longer (females) than pronotum, very slightly (female) or distinctly (male) curved throughout, lamellar process ventrad of antennal insertion not angularly projecting; antennal club rather compact, barely longer than distal four funicular segments combined; pronotum not quite as long as wide, sides subparallel in basal half, roundly constricted apically and subtubulate in front; sides of aedeagus parallel, apex blunt, only middle slightly produced, apodemes shorter than body of aedeagus, internal sac short, basal sclerite absent, tegmen with parameres and basal apodem of subequal length, male sternite 9 with distal appendices very unequal.

Material examined: One series of 30 specimens from Brazil, Santa Catarina Province, Nova Teutonia, October 1974, coll. F. Plaumann (CMNC)

Plant associations: Unknown 
Discussion: The occurrence of a species of Cylindridia in Brazil indicates, that the Middle American species from high elevations are unlikely to be mere glacial relicts of a shared hypothetical Nearctic ancestor. I was not able to identify this species, but suspect that it has been described in a different genus by either Hustache or Bondar. Cylindridia may include several other South American species, and this fauna needs further study.

\section{References}

Anderson, R. S. \& Peck, S. B. 1994: Origin and biogeography of the weevils of southern Florida (Coleoptera: Curculionidae). - The Canadian Entomologist 126: 819-839.

BEDEL, L. 1885 [1882-88]: Faune des Coléoptères du bassin de la Seine. - Annales de la Société Entomologique de France 6: 442 pp.

Bövnng, A. G. 1924: The larva of the weevil Limnobaris rectirostris LeConte. - Jornal of the New York Entomological Society 32: 197-203.

CaseY, T. L. 1892: Coleopterological notices IV. - Annales of the New York Academy of Sciences 6 (7-12): $359-712$.

Casey, T. L. 1920: Some descriptive studies among the American Barinae. - Memoirs on the Coleoptera 9: 300-516.

Chagnon, G. 1917: A preliminary list of the insects of the province of Quebec. Part III - Coleoptera. - Supplement to report of the Quebec Society for the Protection of Plants, Montreal: 165-277.

Dieckmann, L. 1991: Die europäischen Limnobaris-Arten (Coleoptera, Curculionidae). - Beiträge zur Entomologie Berlin 41: 303-311.

Eberhard, W. G. \& Garcia-C., J. M. 2000: Ritual jousting by horned Parisoschoenus expositus weevils (Coleoptera, Curculionidae, Baridinae). - Psyche 103 (1-2): 55-84.

HiLTY, J. 2005: Insect visitors on Illinois wildflowers. - http://www.shout.net (last accessed 6 May 2005).

LeConte, J. L. 1876: - In LeConte, J. L. \& Horn, G. H.: The Rhynchophora of America, north of Mexico. - Proceedings of the American Philosophical Society 15 (96): i-xvi, 1-455.

Majka, C. G.; Anderson, R. A. \& McCorquodale, D. B. submitted: The weevils of the Maritime Provinces of Canada: new records from Nova Scotia and Prince Edward Island (Coleoptera: Curculionoidea). - The Canadian Entomologist.

PALM, T. 1957: Till frågan om de svenska Limnobaris-arterna (Col., Curculionidae). - Entomologisk Tidskrift Uppsala 78: 143-148.

Parnell, J. R. 1970: Observations on the fauna connected directly with sedges of the genus Cyperus in Costa Rica, Central America. I. Sibariops confusus (Bot.) (Col., Curculionidae) on Cyperus ferax L. Ruch. - Revista Biologia Tropicales 16 (2): 247-253.

SATterthWATt, A. F. 1942: Weevils (Col.: Curculionidae) affecting chufa (Cyperus esculentus).--Entomological News 53:11-16.

YoshiHara, K. \& Morimoto, K. 1994: A revision of the baridine weevils of the genus Limnobaris Beder (Coleoptera, Curculionidae) from Japan and neighbouring countries. - Japanese Journal of Entomology $62(3): 445-456$.

Yoshihara, K. \& Mortmoto, K. 1997: Calyptopygus kumei (Coleoptera, Curculionidae), a new species of baridine weevil from Japan and Taiwan. - Elytra 25 (1): 1-5.

\section{Author's address:}

JENS PRENA

E-Mail: baridinae@gmx.de 